\title{
Ethnobotanical Study of Medicinal Plants and Conservation Status Used to Treat Human and Livestock Ailments in Fadis District, Eastern Ethiopia
}

\author{
Bekele Kindie*, Chala Tamiru, Tahir Abdala \\ Ethiopian Biodiversity Institute, Harar Biodiversity Centre, Harar, Ethiopia \\ Email address: \\ kindiebekele21@gmail.cocm (B. Kindie) \\ ${ }^{*}$ Corresponding author
}

To cite this article:

Bekele Kindie, Chala Tamiru, Tahir Abdala. EthnoBotanical Study of Medicinal Plants and Conservation Status Used to Treat Human and Livestock Ailments in Fadis District, Eastern Ethiopia. International Journal of Homeopathy \& Natural Medicines.

Vol. 7, No. 1, 2021, pp. 7-17. doi: 10.11648/j.ijhnm.20210701.12

Received: March 13, 2021; Accepted: April 9, 2021; Published: April 29, 2021

\begin{abstract}
This study was conducted to document medicinal plants, and indigenous knowledge, used to treat human and animal ailments. Eighteen key informants were selected purposely and eighty one informants were selected randomly. Ethnobotanical data were gathered using semi-structured interviews, field observations and group discussions. Data were analyzed using descriptive statistics. The Ethnomedicinal use of forty plant species was recorded distributed as twenty one families. Solanaceae were the highest number of medicinal plants consisting of 6 (28.57\%) species followed by Fabaceae (14.29) species. 18 plant species were used to treat humans, 2 species used to treat livestock and 20 were used for both human and livestock disease. The growth habits of medicinal plants shrubs were highly constituted $(47.5 \%)$ followed by herbs $(32.5 \%)$. Poundings is the highest method of preparation constituted (29.41\%) followed by crushing (16.80\%). The most common used plant parts were the leaves (36.36\%) followed by roots (19.69\%). The most commonly used route of administration was oral followed by dermal. Stomachache, Malaria, evil eye, headache, and intestinal parasite the highest ICF value $>93$. People in the study area have their own ways of managing health problems of humans and livestock. The study indicated that the Fedis district possesses rich indigenous knowledge of medicinal plants and it's used to treat animal and livestock diseases. The major threats to MPs and associated knowledge are lost due to agricultural expansion, charcoal productions, and unsustainable use of medicinal values.
\end{abstract}

Keywords: Ethnobotany, Indigenous Knowledge, Medicinal Plants, Conservation, Informant Consensus Factor

\section{Introduction}

Ethno botany is the study practice of a particular culture and religion of people used to indigenous knowledge and traditional medicinal plants. It also plays an energetic role to draw information on plants and related indigenous knowledge for conservation, generate modernization drugs and sustainable utilization of medicinal plants. In Ethiopia plants have been used as a medicine to treat different diseases integrated with indigenous knowledge and culture. People throughout the world used plants as medicines, diet, ceremonies, social life, assets or income and other purposes [16]. People have continuously developed knowledge of traditional medicinal plant use and its supply administration. Traditional knowledge is the acquisitive organization of knowledge practice and belief by adaptive processes through generation to generation for cultural transmission with one another. In many parts of Ethiopia people depend on traditional knowledge and medicinal plants used to meet their primary health care requirements and income. Diverse grouping of public and cultural experiences of the country contributed to rich indigenous knowledge and using medicinal plants to treat human and livestock ailments. About $80 \%$ of the human population and $90 \%$ of livestock depend on traditional medicine in the country [15]. Traditional medicine is an indigenous medicine that is used to maintain health to prevent, diagnose, and treat physical and mental illnesses inversely from allopathic medicine based on theories, beliefs, and experiences [23]. Traditional medicine has been used for thousands of years with great contributions by practitioners to human health, particularly as primary health care providers at the community 
level and has maintained its popularity worldwide [22]. Ethnobotanical studies through written documents are significant in revealing locally important medicinal plant species particularly for discovery of new drugs [21]. Despite the agroecological and cultural diversity of the country, documentation of medicinal plants and associated indigenous knowledge appears incomplete [13]. The current status of medicinal plants in Ethiopia showed that about 887 plant species are reported to be utilized in traditional medicine [7]. Among these species 26 species are endemic and becoming increasingly rare and rare near to extinction.

Documentation of ethno botanical knowledge on medicinal plants is the basic conservation and raising significantly community participant developments. According to Cunningham, A. B. in situ and ex situ conservations are conservation methods that have been undertaken around the world aimed to protecting threatened medicinal plants from further destruction [6]. Despite this actuality, there is a deficiency of proper conservation and administration that leads to the decrease and lastly extinct of medicinal plant species with negative influences and related indigenous knowledge of the local societies. Therefore, this study was conducted in the following objectives. (1) To characterize traditional medicinal plant species used in the community, (2) To identify and document plant parts used to treat animals and livestock health problems, methods of preparation and route of administration of medicine. (3) To assess the current status of medicinal plants conservation with indigenous knowledge of the community.

\section{Materials and Methods}

\subsection{Description of the Study Area}

The study was conducted at Fadis district, Eastern Hararghe Zone of Oromia Regional State. It is located $658 \mathrm{~km}$ far from Addis Ababa and $33 \mathrm{~km}$ from Harar city. Geographically, study it is located at geographic position at latitude of $08^{\circ} 02^{\prime} 30^{\prime \prime}-09^{\circ} 00^{\prime} 14^{\prime \prime} \mathrm{N}$ and longitude of $42^{\circ} 06^{\prime} 02^{\prime \prime}-42^{\circ} 19^{\prime} 00^{\prime \prime} \mathrm{E}$. The altitude in the sanctuary ranges from 1200 to 2118 masl. Fedis is bordered on the southwest by Gola Odana Meyumuluke, on the west by Girawa, on the northwest by Haromaya, on the north by the Harari Region, on the east by Babile, and on the southeast by the Erer River which separates it from the Somali Region. The administrative center of this woreda is Boko. There were 23 Farmers Associations with 29,713 members and 4 Farmers Service Cooperatives with 346 members (Wikipedia website accessed may 2018). The mean annual temperature is about $20.2^{\circ} \mathrm{C}$, ranging from a mean minimum of $12.8^{\circ} \mathrm{C}$ to mean Maximum of $29.4^{\circ} \mathrm{C}$. There is only a slight difference in temperature throughout the year, with the hottest months during April to June (maximum $28.6^{\circ} \mathrm{C}$ ) and the coldest during October to December (minimum $10.2^{\circ} \mathrm{C}$ ). The mean annual rainfall is $740.6 \mathrm{~mm}$ year, with high variation from year to year, ranging from 470.6 $\mathrm{mm}$ to $1270.4 \mathrm{~mm}$ year. Rainfall is bimodal, occurring from February to April (short rain season) and June to September (long rain season) (Source: National Meteorological Service
Agency of Ethiopia Data from 1965 to 2005).

\subsection{Site Selection}

Purposively three Kebeles were selected for ethnobotanical data collection of medicinal plants. Study Kebeles were agdora, Aanan and lenca kebeles due to the abundance presence of traditional medicinal plants, threatened medicinal plants and biodiversity. From each selected kebeles six key informants (traditional healers) were selected purposely.

\subsection{Selection of Participants}

Following Martin, G. J. for collection of ethno-botanical data, the informants (61 male and 40 female) were selected randomly from the three representative kebeles and 6 individuals from each study kebele were selected as the key informants [11], plus, a selected informant considered with the age of 20 and above was included as key informants to obtain pertinent information while less than 20 age groups were considered to determine the status of knowledge transfer from elders. The totals of $18 \mathrm{key}$ informants were selected purposely with the assistance of peasant association leaders, members of the local authorities, and development agents. Representative common participants and knowledgeable of traditional medicine practitioners (key participants) were selected using random and purposive sampling approaches, respectively following Martin, G. J. [11]. The selection of key participants was also based on the quality of explanations that particular participants were given during an interview. Local healers automatically qualified as key participants being traditional experts who were guardians of indigenous knowledge on medicinal plants.

\subsection{Ethnobotanical Data Collection}

Ethnobotanical data was collected using semi-structured questionnaires, group discussion, guided field walks, and observations with participants from both randomly and purposely selected households based on a checklist of questions prepared in English and translated to 'Afan Oromo', the language of local people and others languages. The data was collected in one season, from November 15, to December 15, 2020. Information was carefully recorded during an interview with a participant. Field observations were performed with the help of local guides on the morphological features and habitats of each medicinal plant species in the field and brief discussion was conducted on threats and conservation of medicinal plants, parts of medicinal plants used to treat diseases, and transferability of knowledge to the community. Verbal consents were also obtained from the participants through performed group discussions about the objectives of the study prior to the interviews, and all data collected by their oral consents. Photographic was used for graphic documentation. Most of the interviews were completed in the field in order to avoid the risk of confusing, identity of plant species via repeated inquiries at least three times with the same and different informants to confirm the validity and reliability of the recorded information. 


\subsection{Plant Species Identification}

Voucher specimens were collected for each plant species pressed, and dried for identification. For some common species, and preliminary identification was done in the field using keys and illustrations.

\subsection{Data Analysis}

Ethnobotanical data was analyzed using descriptive statistics methods following Martin, G. J. for each medicinal plant, the proportion of informants who independently reported use against a particular disease category [11]. The informant consensus factor (ICF) was calculated using the formula of Trotter R. [20].

$$
\mathrm{ICF}=\frac{N u r-N t}{N u r-1}
$$

Where; Nur; is the "number of use-reports" or species used in each disease category and

$\mathrm{Nt}$; is the number of taxa used for a particular use category by all informants.

The fidelity level (FL), the percentage of informants claiming the use of a certain plant for the same major purpose, was also calculated for the most frequently reported diseases or ailments using the following equation [19].

$$
\mathrm{FL}(\%)=\frac{N u}{N} \times 100
$$

Where; $\mathrm{Np}$; is the number of informants that use a plant species to treat a particular disease, $\mathrm{N}$; is the number of informants that use the plants as a medicine to treat any given disease.

\section{Results and Discussions}

\subsection{Socio Demographic and Knowledge Characteristics of Respondents}

In the study showed that sociodemographic of respondents' participants, the number of male $(72.28 \%)$ participants was higher than the number of female $(27.72 \%)$ participants. The age of participants ranged from 20 to 73 . The majority respondents were farmers $(69.31 \%)$ followed by $(16.83 \%)$ house wives. Regarding to educational status, the majority of respondents $45(44.55 \%)$ were illiterate followed by $(37.62 \%)$ were primary school attended with $(37.62 \%)$. Afan Oromo is the dominant spoken language.

\subsection{Knowledge Source and Transfer of Traditional Medicinal Plants Use}

As the study recorded the most important way of transfer of indigenous knowledge's on the use of medicinal plants in the study kebeles were by word of oral to a family member. As study indicated of key informants' fathers constitute $(66.67 \%)$ were the major source of knowledge on traditional medicinal plants. The tendency to share their knowledge on the use of traditional medicinal plants the key informants were transferred their medicinal knowledge were trusted eldest sons constitute $(50 \%)$ followed by trusted son $(27.78 \%)$. This study is line up with the study of Amsalu Nugussie reported that, at family level, it is restricted to the elders (men and women), followed by elder child or their trustworthy person when the mother or the father is getting old or near to die, [3] and reported by Abdurhman Nurya, in Ofla District [1].

\subsection{Plant Species Used Medicinally in Fedis Woreda}

This study was recorded 40 traditional medicinal plant species that used to treat different human and livestock aliments. These medicinal plants are distributed in 21 families. Solanaceae (28.57\%) species were the most frequently cited in the study area followed by Fabaceae, Alliaceae, Asteraceae, Boraginaceae (14.29) species equally. The rest of the species belonged to two and one family each. This traditional medicinal plants species were used to treat 55 different Human and Livestock health problems. So $(45.00 \%)$ species were used to treat human ailments and $(5.00 \%)$ species used to livestock and $(50.00 \%)$ species used to treat both human and livestock ailments (Table 1). This study is line up with the study conducted by Megersa Moa in Wayu Tuka district, Oromia Region of Ethiopia [12].

\begin{tabular}{|c|c|c|c|c|c|c|c|c|}
\hline & Scientific name & family & Local name & На & $\begin{array}{l}\text { Types Ailment } \\
\text { treated }\end{array}$ & & Methods of preparations & $\begin{array}{l}\text { Routes of } \\
\text { Administrations }\end{array}$ \\
\hline \multirow{4}{*}{1} & \multirow{4}{*}{ Allium sativum. } & \multirow{4}{*}{ Alliaceae } & \multirow{4}{*}{ Qullubbii } & \multirow{4}{*}{$\mathrm{H}$} & Cough* & Bulb & $\begin{array}{l}\text { The dried bulb is pounded, mixed with honey } \\
\text { and } 2-3 \text { teaspoon is eaten Every day for five } \\
\text { days. }\end{array}$ & Oral \\
\hline & & & & & Evil eye* & Bulb & $\begin{array}{l}\text { The dried bulb is crushed together with one } \\
\text { rhizome of Zingiber officinale with honey and } 3 \\
\text { tea spoons are taken. }\end{array}$ & Oral \\
\hline & & & & & Malaria* & Bulb & $\begin{array}{l}\text { The fresh bulb is pounded, mixed with the } \\
\text { crushed fresh leaves of Ruta chalepensis, and } \\
\text { applied externally }\end{array}$ & Dermal \\
\hline & & & & & Wound* & Bulb & $\begin{array}{l}\text { The dried bulb is pounded and tied on the } \\
\text { wound every two days for one week days. }\end{array}$ & Dermal \\
\hline 2 & Allium cepa. & Alliaceae & Shunkurtii & $\mathrm{H}$ & Poisoning* & Root & $\begin{array}{l}\text { Tie up the dried root powder with the leaf } \\
\text { concoction of Vernonia amygdalina }\end{array}$ & Dermal \\
\hline \multirow[t]{2}{*}{3} & \multirow{2}{*}{ Aloe macrocarp. } & \multirow[t]{2}{*}{ Aloaceae } & \multirow[t]{2}{*}{ Argiisa } & \multirow[t]{2}{*}{$\mathrm{H}$} & $\begin{array}{l}\text { Intestinal } \\
\text { parasite*** }\end{array}$ & Leaf & Fresh leaves chewed and swallow the juice. & Oral \\
\hline & & & & & Leprosy* & Leaf & Fresh Leaves are pounded and mixed with butter & Dermal \\
\hline
\end{tabular}

Table 1. List of medicinal plants used for treating human and animal ailments in the study area, Where (Ha: habit, S: shrub, C: climber, T: tree, and H: herb). 


\begin{tabular}{|c|c|c|c|c|c|c|c|c|}
\hline & Scientific name & family & Local name & На & $\begin{array}{l}\text { Types Ailment } \\
\text { treated }\end{array}$ & & Methods of preparations & $\begin{array}{l}\text { Routes of } \\
\text { Administrations }\end{array}$ \\
\hline \multirow{4}{*}{4} & \multirow{4}{*}{$\begin{array}{l}\text { Azadirachta } \\
\text { indica. }\end{array}$} & \multirow{4}{*}{ Meliaceae } & \multirow{4}{*}{ Nimii dhugaa } & \multirow{4}{*}{$\mathrm{T}$} & Bloat** & Leaf & $\begin{array}{l}\text { and painting on the skin. } \\
\text { Fresh Leaves Chewed and mixed with water and } \\
\text { drinking }\end{array}$ & Oral \\
\hline & & & & & Nose bleeding* & Leaf & $\begin{array}{l}\text { Fresh Leaves are crushed and tie on The wound } \\
\text { and squeeze in to the nose. This helps to stop } \\
\text { nose bleeding. }\end{array}$ & Nasal \\
\hline & & & & & Lice** $^{* *}$ & Leaf & $\begin{array}{l}\text { First fresh leaves are prepared and painting on } \\
\text { cattle skin. }\end{array}$ & Dermal \\
\hline & & & & & Tick** & Stem & $\begin{array}{l}\text { Fresh stem grounded and polishing the bitten } \\
\text { area. }\end{array}$ & Dermal \\
\hline 5 & $\begin{array}{l}\text { Bidens } \\
\text { macroptera }\end{array}$ & Asteraceae & Keelloo & S & Athletes foot* & Leaf & $\begin{array}{l}\text { Fresh Leaves put on fire and rubbed on affected } \\
\text { part. }\end{array}$ & Dermal \\
\hline 6 & $\begin{array}{l}\text { Buddleia } \\
\text { polystachya }\end{array}$ & Loganiaceae & Adaaddo & $\mathbf{S}$ & Diarrhea* & Seed & $\begin{array}{l}\text { The dried Seeds are pounded, mixed with honey } \\
\text { and eating. }\end{array}$ & Oral \\
\hline \multirow{6}{*}{7} & \multirow{6}{*}{ Calpurnia aurea } & \multirow{5}{*}{ Fabaceae } & \multirow{5}{*}{ Ceekaa } & \multirow{6}{*}{$\mathrm{S}$} & Lice** $^{* *}$ & Leaf & $\begin{array}{l}\text { Fresh leaves are pounded, mixed with water and } \\
\text { wash the body of the animal every morning until } \\
\text { the parasites are eradicated. }\end{array}$ & Dermal \\
\hline & & & & & Diarrhea*** & Leaf & $\begin{array}{l}\text { Fresh leaves are chewed and swallow for } \\
\text { humans and leaf is pounded, mixed with water } \\
\text { and drinking to animal until the diarrhea stops. }\end{array}$ & Oral \\
\hline & & & & & Syphilis* & Seed & $\begin{array}{l}\text { The dried seeds are crushed, mixed with honey } \\
\text { and one teaspoon is eaten for five consecutive } \\
\text { days. }\end{array}$ & Oral \\
\hline & & & & & Leech** & Leaf $/$ seed & $\begin{array}{l}\text { Fresh leaf or seed are pounded together with } \\
\text { leaf of Nicotiana tabacum and are drinking } \\
\text { through the nostrils. }\end{array}$ & Nasal \\
\hline & & & & & Snake bite* & Leaves & The decocted leaves are drinking with Honey & Oral \\
\hline & & \multirow{3}{*}{ Capparidaceae } & \multirow{3}{*}{ Harangamaa } & & Swelling** & Root & $\begin{array}{l}\text { Dried root is pounded, mixed with butter and } \\
\text { painting to the affected breast. }\end{array}$ & Dermal \\
\hline \multirow[t]{2}{*}{8} & \multirow[t]{2}{*}{$\begin{array}{l}\text { Capparis } \\
\text { tomentosa }\end{array}$} & & & \multirow[t]{2}{*}{ S } & Toothache* & Leaf & $\begin{array}{l}\text { The fresh leaf is chewed and holding on the } \\
\text { teeth for } 2-3 \text { hours. }\end{array}$ & Oral \\
\hline & & & & & Evil eye* & Leaf /seed & $\begin{array}{l}\text { Dried Leaf or root is crushed, add to fire and } \\
\text { smoked }\end{array}$ & Dermal \\
\hline 9 & $\begin{array}{l}\text { Capsicum } \\
\text { annuиm }\end{array}$ & Solanaceae & Barberee & $\mathrm{H}$ & Bloat** & Fruit & $\begin{array}{l}\text { Dried fruit Pounded, mixed with water and } \\
\text { given orally }\end{array}$ & Oral \\
\hline 10 & Citrus limon & Rutaceae & Loomii & $\mathrm{S}$ & $\begin{array}{l}\text { Stomach } \\
\text { ache* }\end{array}$ & Fruit & $\begin{array}{l}\text { Fresh Fruit of Citrus limon and Allium sativum } \\
\text { are pounded together and mixed with honey and } \\
\text { eaten with wheat bread. }\end{array}$ & Oral \\
\hline 11 & Catha edulis & Celastraceae & Caatii & S & $\begin{array}{l}\text { Urine } \\
\text { retention*** }\end{array}$ & Leaf & $\begin{array}{l}\text { Fresh leaf } i \text { s pounded, mixed with water add } \\
\text { areke and given }\end{array}$ & Oral \\
\hline \multirow[t]{2}{*}{12} & \multirow[t]{2}{*}{ Coffea Arabica. } & \multirow[t]{2}{*}{ Rubiaceae } & \multirow[t]{2}{*}{ Buna } & \multirow[t]{2}{*}{ S } & Wound * & Seed & $\begin{array}{l}\text { Roast seed pounded and mixed with honey then } \\
\text { eaten or drunk in to empty stomach for } 2-3 \text { days. }\end{array}$ & Oral \\
\hline & & & & & $\begin{array}{l}\text { continuous flow } \\
\text { menstruation* }\end{array}$ & Bark & $\begin{array}{l}\text { Fresh or dried bark drunk with one coffee cup } \\
\text { for four consecutive days }\end{array}$ & Oral \\
\hline \multirow[t]{2}{*}{13} & \multirow[t]{2}{*}{$\begin{array}{l}\text { Cordia africana } \\
\text { Lam. }\end{array}$} & \multirow[t]{2}{*}{ Boraginaceae } & \multirow[t]{2}{*}{ Waddeessa } & \multirow[t]{2}{*}{$\mathrm{T}$} & $\begin{array}{l}\text { prevent } \\
\text { bleeding } \\
\text { flow*** }\end{array}$ & Bark & $\begin{array}{l}\text { Fresh or dried bark drunk with one coffee cup } \\
\text { for four consecutive days. }\end{array}$ & Oral \\
\hline & & & & & Itching* & Root & $\begin{array}{l}\text { The roots are powdered then painted at bed time } \\
\text { for } 5 \text { days }\end{array}$ & Dermal \\
\hline \multirow[t]{8}{*}{14} & \multirow[t]{8}{*}{$\begin{array}{l}\text { Croton } \\
\text { macrostachyus }\end{array}$} & \multirow[t]{8}{*}{ Euphorbiaceae } & \multirow[t]{8}{*}{ Bakkanniisa } & $\mathrm{T}$ & Ascaris* & Leaf/ bark & $\begin{array}{l}\text { fresh young leaf and bark pounded, boiled, add } \\
\text { butter, cool three tablets for children, five to ten } \\
\text { tablets for elders is }\end{array}$ & Oral \\
\hline & & & & & prevent alargic* & Leaf/ bark & $\begin{array}{l}\text { The tip of fresh young leaf and the bark is } \\
\text { pounded, boiled; add butter and three tablets for } \\
\text { children, five to ten tablets for elders is given. }\end{array}$ & Oral \\
\hline & & & & & Ringworm* & Latex & Sap applied on the skin. & Dermal \\
\hline & & & & & Bloat** & Bark & $\begin{array}{l}\text { The fresh bark is mixed with water and given to } \\
\text { the animal }\end{array}$ & Oral \\
\hline & & & & & Jaundice* & Leaf & Fresh leaf Cooked, pasted with honey and eaten. & Oral \\
\hline & & & & & Gonorrhea* & Leaf & $\begin{array}{l}\text { Fresh leaf tips is cut, cooked and two spoon of } \\
\text { solution is drunk } 5 \text { consecutive days. }\end{array}$ & Oral \\
\hline & & & & & Stomach ache* & Bark & $\begin{array}{l}\text { Fresh bark pounded with bulb Allium sativum, } \\
\text { mixed butter }\end{array}$ & Oral \\
\hline & & & & & $\begin{array}{l}\text { Skin rash } \\
\text { (chiffe) } *\end{array}$ & leaf bud & $\begin{array}{l}\text { Fresh shoot is cut and the fluid applied to the } \\
\text { rash }\end{array}$ & Dermal \\
\hline 15 & Olea europaea & Oleaeceae & Ejersa & $\mathrm{T}$ & Itchy skin* & Leaf & Fresh leaf boiled in water and steams the vapour & Dermal \\
\hline
\end{tabular}




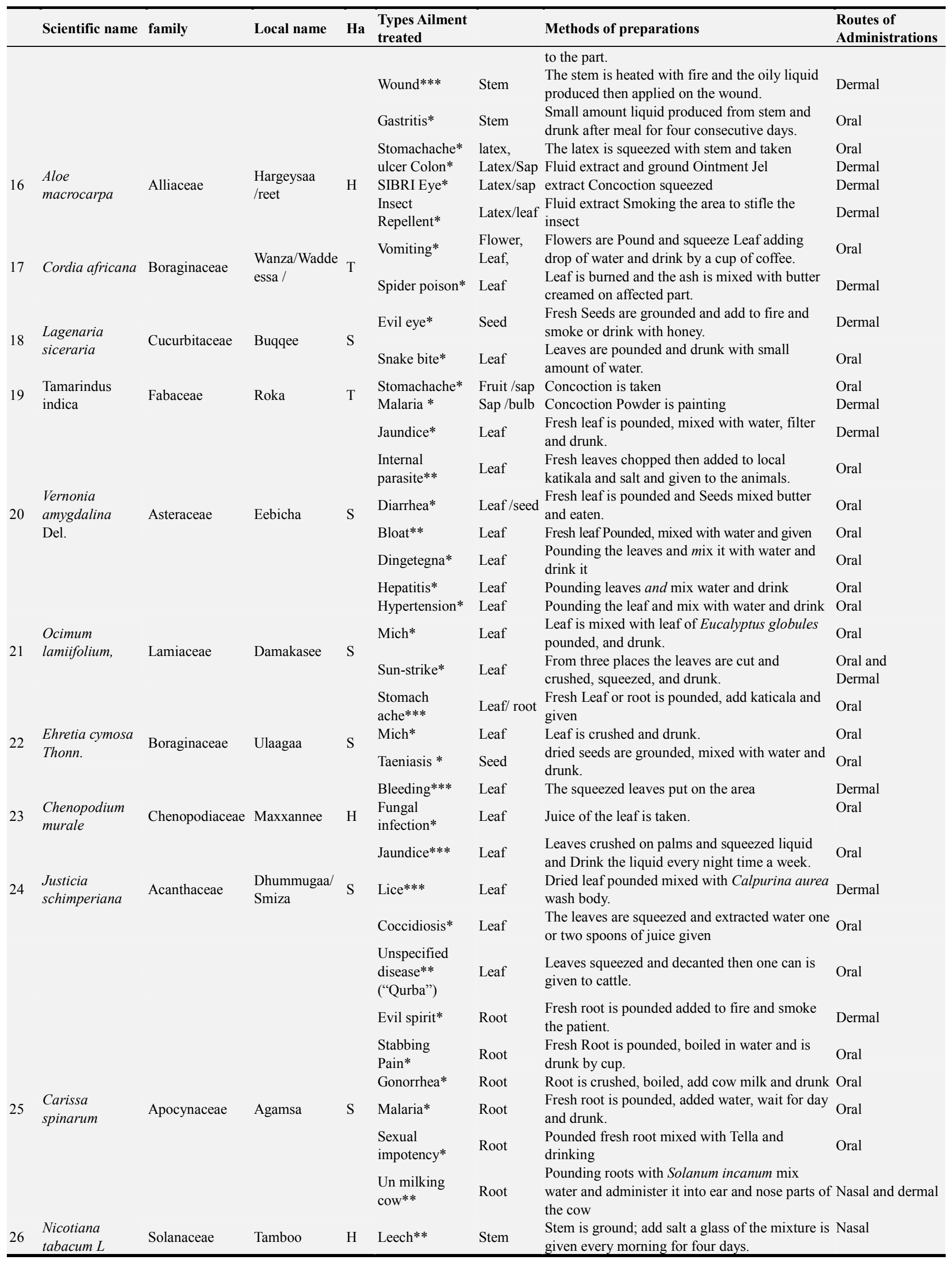




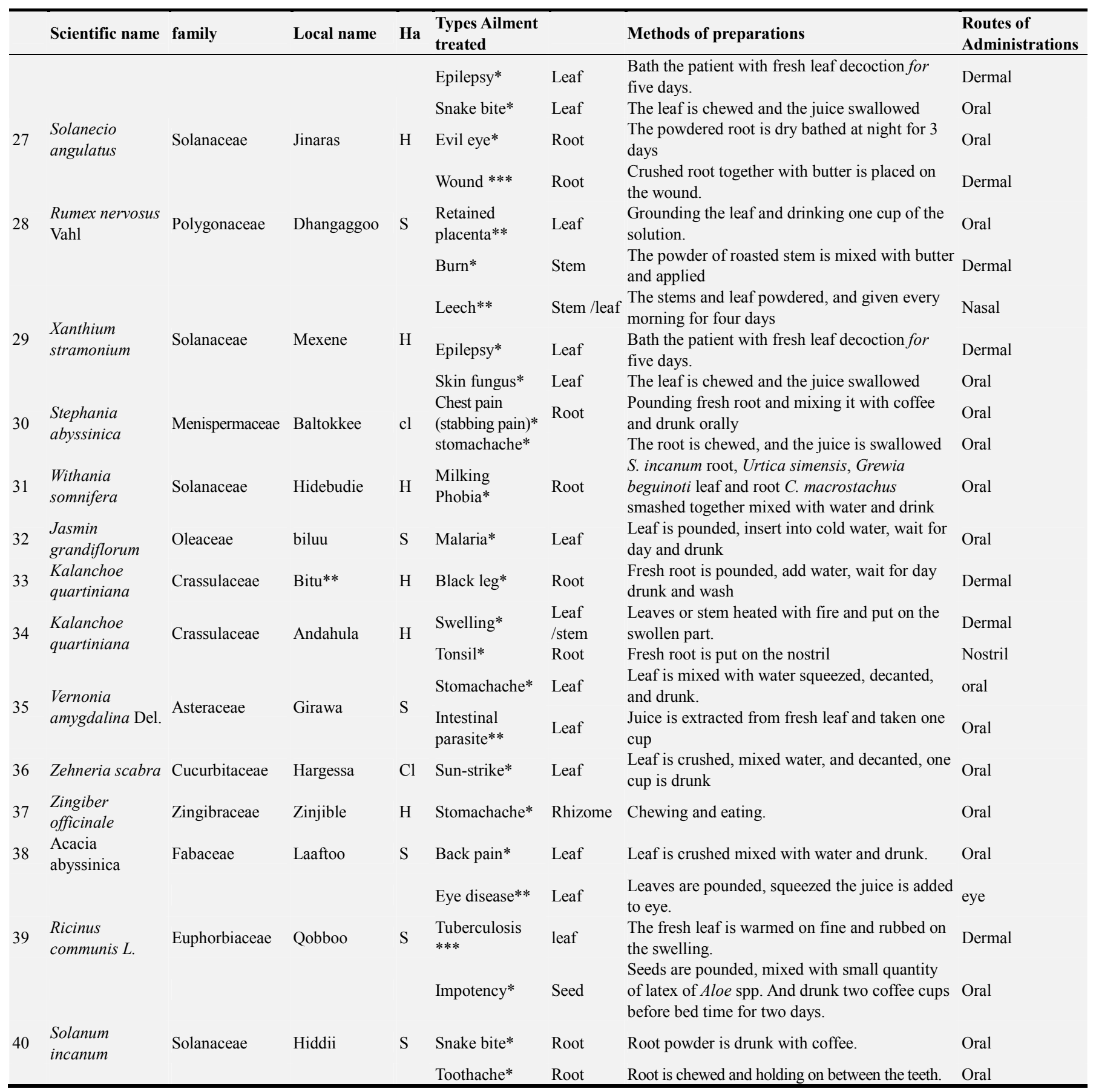

Key:-Animal disease** Human disease* Animal and human disease**

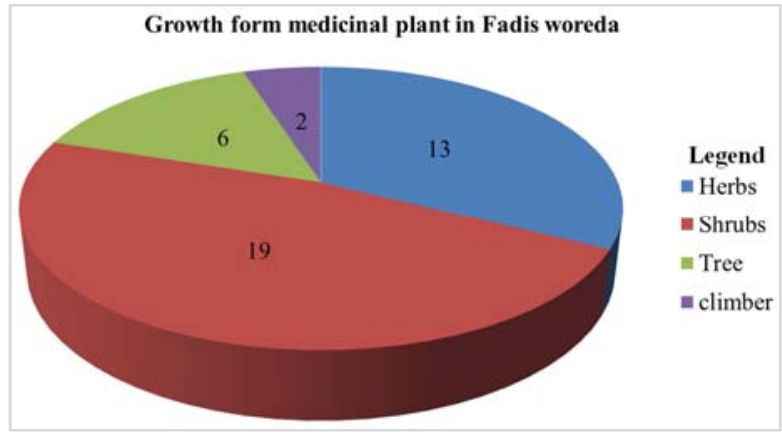

Figure 1. Growth form of medicinal plants in the study area.

\subsection{Growth Habits of Medicinal Plants}

Based on the study recorded the growth habits of medicinal were constitute shrubs $19(47.5 \%)$, herbs 13 $(32.5 \%)$, trees $6(15.00 \%)$, climbers $2(5.00 \%)$ (Figure 1). As the result indicated, shrubs were the highest growth habits followed by herbs. This study is line up with Trotter R. found herbs to be the most utilized plants, accounted for $44 \%$ of the species, followed by shrubs $29 \%$ in Kilte Awulaelo district, Tigray Region of Ethiopia [20]. 


\subsection{Plant Parts Used to Prepared Remedies in the Study Area}

The study indicated the plant parts used for medication preparation by the traditional healers are variable. The plant parts in the preparation of remedies were leaves $24(36.36 \%)$, root $13(19.69 \%)$, seeds $7(10.60 \%)$, stem $6(9.09 \%)$, bark 5 (7.58\%), fruit $3(4.55 \%)$, bulb $3(4.55 \%)$, flower $2(3.03 \%)$, latex $2(3.03 \%)$, rhizomes $1(1.52 \%)$. As the result showed leaves were the most commonly used parts of medicinal plants followed by roots (Figure 2). This study is line up with the reported by [10] that the most commonly used part of the medicinal plants was leaves 129 (38.62\%), followed by roots accounting $57(17.06 \%)$ in Ganta Afeshum district, Eastern Zone of Tigray, Northern Ethiopia.

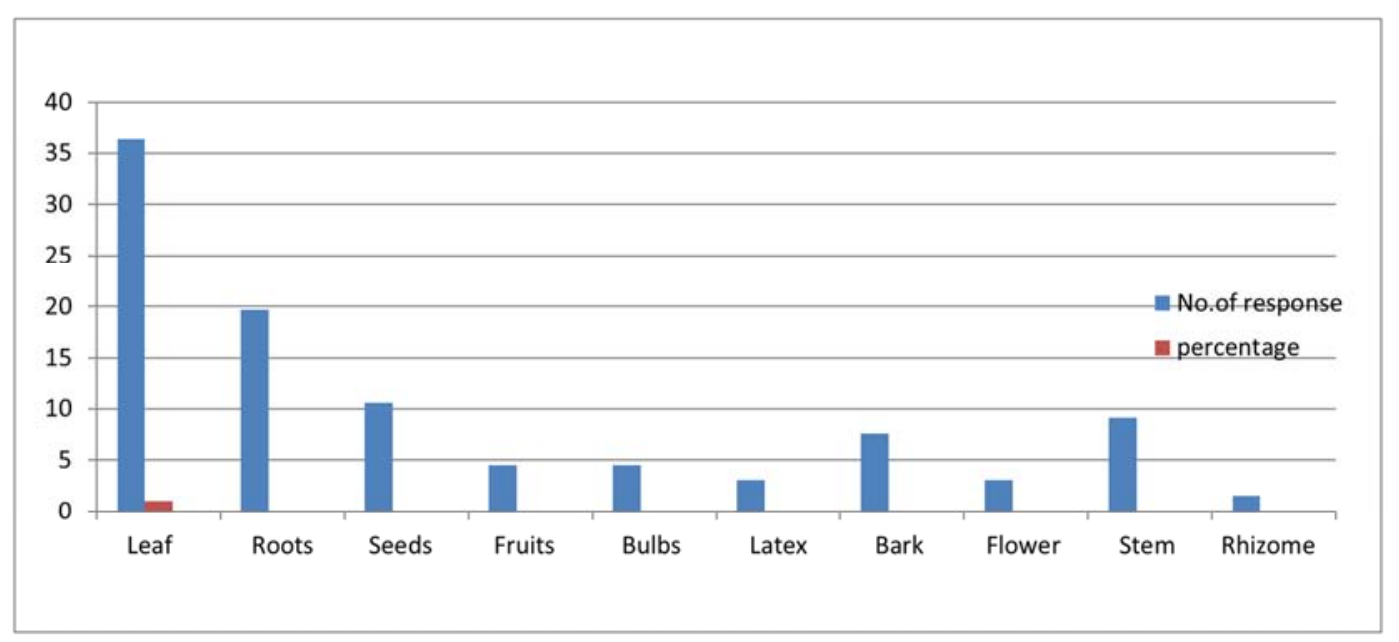

Figure 2. Plant parts used for traditional medicine preparations in the study area.

\subsection{Method of Preparation Remedies from Traditional Medicinal Plants}

Regarding the preparation of traditional medicine, the local people are used different methods of preparation of traditional medicines for different types of diseases. The preparations vary based on the type of disease treated and the actual site of the diseases. As study revealed the most methods of preparation were in the form of pounding $29.41 \%$, followed by crushing $16.80 \%$, powdering $14.29 \%$ and chewing $13.44 \%$, respectively (Figure 3 ). This study is line up with a study conducted by Tadesse Abiyot in Guduru district of Oromia Regional state of Ethiopia that the highest traditional medicines were prepared by pounding which accounted $33.3 \%$ followed by crushing $24.6 \%$ [17]. As the interview people reported that some other products are used as additives in their preparations of medicine. Water, oil, sugar, salt, milk, butter, honeys, Teff flour, Soda ash, ground honeys, soil and charcoal ash are some of the additive substances. These additives substances are used to improve the flavor and reduce adverse effects such as vomiting and diarrhea so that the effectiveness of the traditional medicine would be increased. This study is line up with research reported by Mulugeta Kuma [14].

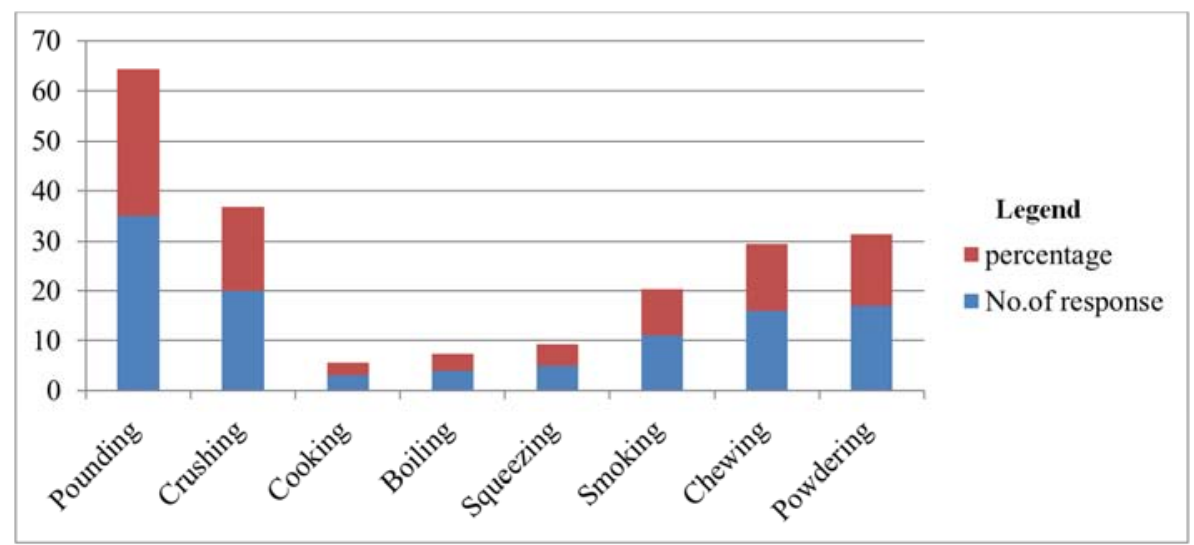

Figure 3. Methods of preparation of traditional medicinal plants remedies in the study area.

\subsection{Route of Remedy Administration and Dosage of Traditional Plants}

The study indicated the most popular rout of remedies administration were oral $(49.30 \%)$, followed by dermal (37.31\%), while nose $6(8.95 \%)$, eye $1(1.49 \%)$, nose and dermal $1(1.49 \%)$, and oral and dermal $1(1.49 \%)$ were the least popular rout of administration respectively (Figure 4). 
This study agrees with the studies conducted by Giday

which accounted $39 \%$ followed by oral $33 \%[8]$. Mirutse, that the highest route of administration was dermal

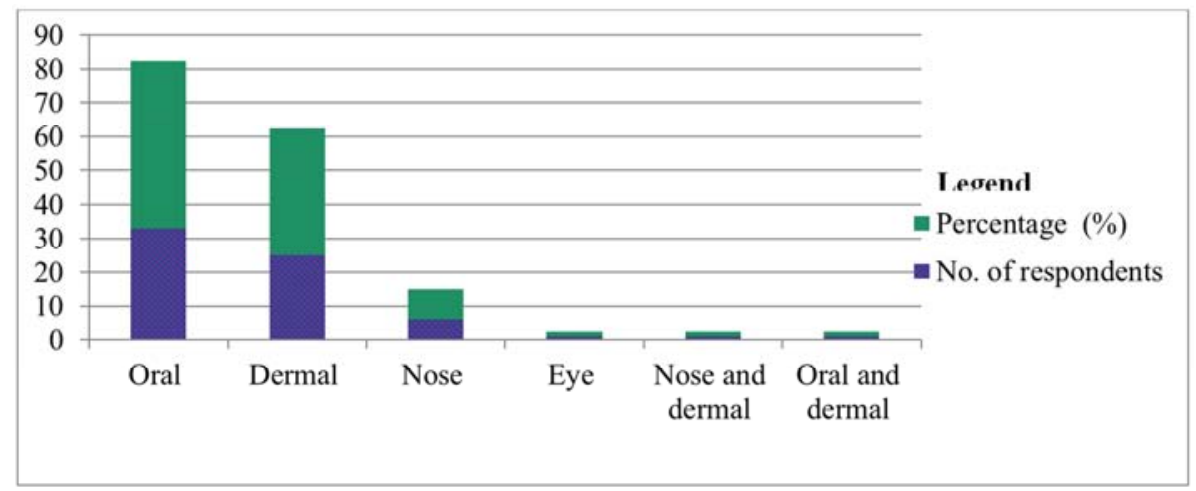

Figure 4. Route of administration of traditional medicine used for treatment.

As the study recorded the dosage of traditional medicine administrations of healers were used different measurements of the dose of traditional remedies. The Coffee cup, tine, finger line, teaspoon, tea glass, and the number of powder droplets picked by finger were used to measure the dose of traditional remedies. The healers also determined dosages of traditional medicines were based on gender, age, physical condition and appearance of patients using their experiences in the study area. As the key informants this methods of dosage determinations were Lack of precision and standardization and have drawbacks for the recognition of traditional health care method. The dosage of traditional plants remedies given to a patients in the study areas have no standardized known unit of measurements. As the information gathered from the key informants taking over dosage or under dosage may lead different health problems. This study is line up with the study conducted by Chekole Getnet in Gubalafto district, Northern Ethiopia indicated that lack of precision and standardization as one of the drawbacks for the recognition traditional health care systems [5].

\subsection{Method of Preservation of the Remedies and Storage Methods}

As the study Healers stored the collected traditional plant medicines in their homes for further usage, mostly in powdered and raw dried forms. Based on the information gathered from the key informants the highest method of preservation was fresh $(46.58 \%)$ followed by fresh/dry $(30.55 \%)$, while the $(22.48 \%)$ were in the form of dry. The majority of remedies preparation was from fresh parts of medicinal plants. Traditional healers store the dried plant medicines in different containers in their homes. The study recorded the methods of local healers preservation of medicinal plants remedies and the knowledge of them were clay, container, plastic bags, Roof hanging, Cloths sheet, and sealed bottles. In this regard, clothes and plastic bags were used mainly to store the dried medicine. This result is line up with the study conducted by Gebrehiwot Mengistu, the highest condition of remedies preparation was from fresh material that accounted for (49.68\%), followed by fresh/dry (35.48\%) [9].

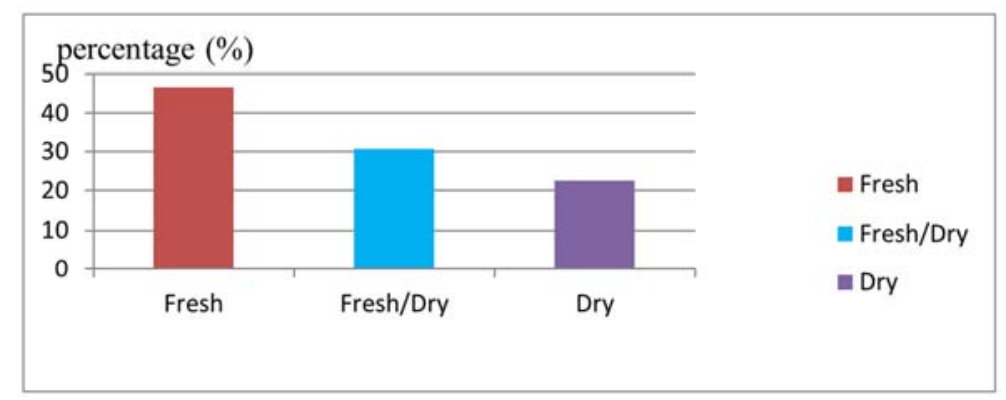

Figure 5. Condition of plant parts for preparation of traditional medicine.

\subsection{Informant Consensus}

The study of medicinal application used informant consensus analysis showed that some medicinal plants were more popular than others. As a result indicated Crotonmacrostachyus constituted 8 (25.8\%) followed by Aloemacrocarpa 6 (19.35\%) was cited by informants (Figure 6). Informant consensus values give good indication about particular species that serve for particular health problems and about specific medicinal plants used for several health problems. The informant consensus obtained during this study indicated that some medicinal plant species are more popular than others. Such information underlines the pharmacological significance of the medicinal plants in the study area. It is indicated that Crotonmacrostachyus, Aloemacrocarpa, Alliu sativum and Zingiber officinale were the three most cited medicinal plant species in the study area (Figure 6). Wound, tonsillitis and abdominal pain were the 
most cited ailments in Fedis Oromia District. According to [4] medicinal plants with higher informant consensus need to be seriously considered for further ethno-pharmacological studies because they are the species that are widely applied by many people and may have been utilized for a long period.

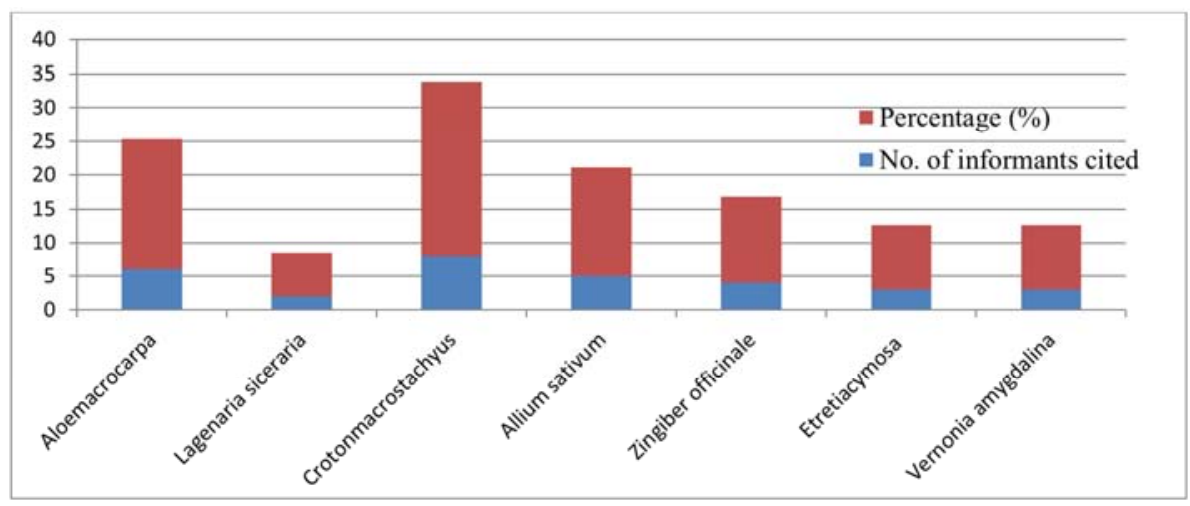

Figure 6. Informant consensus of medicinal plants used for the treatment of ailments in the study area.

\subsection{Informant Consensus Factor (ICF) and Fidelity Level}

The diseases of the study area have been grouped into different categories based on the site of incidence of the disease, condition of the disease as well as treatment resemblance of the disease to the local people. Analysis of ICF showed that values ranged from 0.72 to 0.94 for the diseases categories (Table 2). Of the disease categories,
Malaria and head ache had the highest ICF value suggesting the common occurrence of these problems and agreement of the people on their remedy. It has been showed that medicinal plants that are effective in treating certain diseases and well known by community members have higher ICF values. Gonorrhea, kidney problem and Jaundice, had the lowest $(0.77)$ ICF value, which may be due to the rare occurrence of these diseases.

Table 2. Informant Consensus Factor (ICF).

\begin{tabular}{|c|c|c|c|}
\hline Disease categories & $\mathbf{N t}$ & Nur & ICF \\
\hline Stomachache, malaria wound and headach & 6 & 94 & 0.94 \\
\hline Intestinal parasite and Evil eye & 6 & 95 & 0.94 \\
\hline Swelling and bloating & 8 & 99 & 0.92 \\
\hline Nose bleeding and toothache & 5 & 60 & 0.93 \\
\hline Burn, tonsil and jaundice & 9 & 54 & 0.84 \\
\hline Gonorrhea, athletes foot, poisoning and much & 11 & 45 & 0.76 \\
\hline Eye diseases, impotency and syphilis & 13 & 44 & 0.72 \\
\hline
\end{tabular}

Regarding effectiveness of medicinal plant species to treat a particular disease, and used to treated any given disease were determined by fidelity level. Based on the study the fidelity level (FL) is an index, which shows the specificity of a given plant to effectively treat a particular disease. Fidelity level was then calculated for some commonly used medicinal plants to treat ailments. As the result showed that Allium sativum has the highest FL followed by Crotonmacrostachyus (Table 3). The medicinal plants that are widely used by the local people to treat ailments have higher FL values than those that are less popular [14].

Table 3. Fidelity index of some medicinal plants.

\begin{tabular}{|c|c|c|c|c|c|}
\hline Name of Medicinal Plants & Examples of ailment treated & Np & $\mathbf{N}$ & FL & FL\% \\
\hline Allium sativum & Stomachache, Evil eye and malaria & 56 & 58 & 0.96 & 96 \\
\hline Crotonmacrostachyus & Allergic and skin rash & 50 & 55 & 0.90 & 90 \\
\hline Aloemacrocarpa & Nose bleeding, and bloating & 45 & 51 & 0.88 & 88 \\
\hline Vernonia amygdalina & Diarrhea and hypertension & 41 & 48 & 0.85 & 85 \\
\hline Citrus limon & Stomachache & 38 & 46 & 0.82 & 82 \\
\hline Zingiber officinale & Stomach pain & 35 & 44 & 0.79 & 79 \\
\hline Justicia schimperian & Coccidiosis and Qurba & 28 & 36 & 0.77 & 77 \\
\hline Ocimum lamiifolium & Mich and sun strike & 22 & 29 & 0.75 & 75 \\
\hline
\end{tabular}

\subsection{Threats and Conservation of Indigenous Knowledge, and Traditional Medicinal Plants}

As discussed with the key informants several factors were recorded to threats medicinal plants in the study area. Charcoal production, and fence construction, settlements, overgrazing and urbanization frequently occurred in the study area. Traditional healers also keep their knowledge on medicinal 
plants for the sake of securing means of income and a cultural belief that telling information may make plants ineffective to cure the ailments. Similar findings were reported by Abebe Ayele, elsewhere [2]. According to the respondents, access to modern medication has also contributed to the loss of indigenous knowledge as new generations to give less attention to traditional medicinal plants. As a result the indigenous knowledge seems to be endangered in the study area. People of the study area practice some conservation measurements of medicinal plants are found in household gardens and farm borders as it needs to their daily life as medicine or other values. Medicinal plants also maintained or conserved due to its smell, spiritual value, income sources, and live for keeping enemies, as spices and as food.

\section{Conclusions and Recommendations}

As conclusion people in the study area have significant amount of indigenous knowledge on traditional medicine. Indigenous people of the study area have their own ways of managing health problems of human and livestock as they have a power with specific cultural methods, and tradition knowledge. There is hindrance of transfer knowledge from the elders to the young generation. Ethno-botanical data collected from the study area by means of field walk indicated most of the local people used traditional medicine prepared from plant parts during infection for both humans and livestock in different dosages based on the type of ailments. The accessibility of medicinal plants is decreased during the dry season when it becomes difficult to find especially the herbs in the study area. A total of 40 species of medicinal plants distributed through 21 families were recorded. Solanaceae species was represented the highest number plant species, followed by Alliaceae. Shrubs were the dominant growth habits, followed by Herbs. Leaves were the dominant plant parts used in the preparation of remedies, followed by roots. The most common method of remedy preparation was pounding followed by crushing. Oral was the major route of administration followed by dermal. Most herbal remedies were prepared and preserved from fresh of plants followed by fresh/dried plants. Among 40 species of medicinal plants $(45.00 \%)$ used to treat human, while $(5.00 \%)$ species used to treat livestock and $(50.00 \%)$ species used to treat both livestock and human ailments. The wild habits of plants were the major source of medicinal plants. With regard to the dosage of traditional medicinal plants, there is no standardized measurement. Healers must be modernized to the dosage by discussing with regarding to modern health system measurement. Healers in the study area are not interested to collaborate with other knowledgeable people and healers, so the important information can be lost when medicinal plans were lost or a traditional medical practitioner dies without transferring indigenous knowledge to others. However threats of indigenous knowledge and medicinal plants are oral based transfer, unwillingness of young generation to gain the knowledge, and influence attribute of modern health services and physicians. A conservation effort made by the communities to conserve medicinal plants is unsatisfactory. They must be cultivating and conserve medicinal plants in the natural habitats, on farm land and home gardens and exceptional attention should be given to the medicinal plants that were the most threatened ones. This study is line up with reported by [10].

As the study finding the following recommendations are progressed.

1) Rising the understand of local communities to conserve and protect tradition medicinal plants associated with indigenous knowledge of healers.

2) Encouraging the young generation to avoid destructive impacts on traditional Medicinal plants and associated knowledge in the area.

3) Give training and aware to the communities to conserve traditional medicinal plants through cultivating in home garden and farmland;

4) Encourage the local healers' practitioners to progress the use of traditional medicine preparations through licensing and other motivations;

5) Improved standardized measurement of traditional medication plants remedies dosage

\section{Declarations}

\section{Authors' Contributions}

All authors were involved in data collection and writing of the manuscript as well as read and approved the final manuscript for submission and publication.

\section{Competing Interests}

All authors declare that there are no competing interests.

\section{Availability of Data and Material}

The recorded raw data used for analysis and supplementary information files is available at the author's hand and within the article.

\section{Acknowledgements}

The authors' special word of thanks is to Ethiopian biodiversity institute, Harar biodiversity center and the studied area of local communities who were so kind and willing to supply us with information on traditional medicinal plants. Secondly I would like a great thanks to Enhanced Management and Enforcement of Ethiopia's Protected Area Estate to give deep information.

\section{References}

[1] Abdurhman Nurya, (2010). Ethnobotanical Study of Medicinal Plants Used by Local People in Ofla Wereda, Southern Zone of Tigray Region, Ethiopia.

[2] Abebe Ayele, (2017). Ethnobotanical Study of Medicinal Plants Used by the People of Tarmaber District, Amhara Region, Ethiopia. M. Sc. Thesis, Haramaya University.

[3] Amsalu Nugussie, (2015). An ethnobotanical study of medicinal plants in Farta District, Gondar Zone of Amhara Region, Ethiopia,” pp. 28-55. 
[4] Alemayehu Kefalew, (2015): Ethnobotany of medicinal plants in Ada'a District, Oromia regional, Ethiopia. Journal of ethnobiology and ethnomedicine.

[5] Chekole Getnet, (2017). Ethno study of medicinal plants used against human ailments in Gubalafto District, Northern Ethiopia. Journal of ethnobiology and ethnomedicine.

[6] Cunningham, A. B. (1996). People, Park and plants use recommendations for multiple use zones and development alternatives around Bwindi: Impenetrable National Park, Uganda.

[7] Ermias Lulekal, (2013), Ethnomedicinal study of plants used for human ailments in Ankober District, Amhara, Ethiopia, Journal of Ethnobiology and Ethnomedicine, 9 (63)

[8] Giday Mirutse, (2009). Medicinal plant knowledge of the Bench ethnic group of Ethiopia: an ethnobotanical investigation. Journal of Ethnobiology and Ethnomedicine.

[9] Gebrehiwot Mengistu, (2010). An ethnobotanical study of medicinal plants in Seru wereda, Oromia, Ethiopia.

[10] Leul Kidane and Gebremedhin Gebrecherkos,(2018) Ethnobotanical study of medicinal plants in Ganta Afeshum District, Tigray, Ethiopia. Journal of ethnobiology and ethnomedicine.

[11] Martin, G. J. (1995). Ethnobotany: A method Manual. Chapman and Hall, London. Pp. 265- 270.

[12] Megersa Moa, (2013). ethno botanical study of medicinal plants in Wayu Tuka district, Oromia regional, West Ethiopia. Journal of Ethno Biological and Ethno Medicine, 9: 68.

[13] Mesfin Tadesse, (2005). Medicinal plants used to treat human diseases in Seka cherkosa, Jimma zone, Ethiopia. Ethiopian Journal of Health. 15: 89-106.
[14] Mulugeta Kuma, (2014). Use and management of medicinal plants by indigenous people of Jimma rare district in oromia region, Ethiopia.

[15] PGRC, (1996). Report of the FAO international technical conference on plant genetic resources.

[16] Samar, R., (2015). Ethnobotanical Study of Traditional Medicinal Plants Used By Tribe of Guna District, Madhya Pradesh, India, 4 (7): 466-471.

[17] Tadesse Abiyot (2018). Ethnobotanical study of medicinal plants used to treat human ailment in Guduru District, Oromia, Ethiopia. Journal of Pharmacognosy and Phytotherapy.

[18] Teklay Abraha, (2013). Ethnobotanical study of medicinal plants in Kilte Awulaelo in Tigray Ethiopia. Journal of ethnobiology and ethnomedicine 9 (1): 65.

[19] Teklehaymanot Tilahun, (2007). Ethnobotanical study of medicinal plants in Zegie Peninsula, Northwestern Ethiopia. Journal of ethnobiology and Ethnomedicine 3 (1): 12.

[20] Trotter R, (1986). Informant Consensus: A New Approach for Identifying Potentially Effective Medicinal Plants. In: Etkin NL, editors. Plants in Indigenous Medicine and Diet: Biobehavioural Approaches.

[21] Wright, C. W, (2005). Plant derived anti-malarial agents; new leads and challenges. Phytochemistry.

[22] WHO, (2008). Traditional medicine. http://www.who.int/mediacentre.

[23] WHO, (2012). Traditional medicine. http://www.who.int/mediacentren. 